\title{
ApresentaçÃo do Dossiê \\ POR UMA ANÁLISE NATURALISTA DA NARRATIVA \\ - MENTE, EVOLUÇÃO, COGNIÇÃO E LINGUAGEM
}

\section{Pedro Dolabela Chagas*}

Nos dias 14 e 15 de dezembro do ano passado, organizado pelo NERO (Núcleo de Estudos do Romance) e com apoio do DELLIN (Departamento de Literatura e Linguística), aconteceu na UFPR o "Colóquio Letras e Filosofia: Por uma análise naturalista da narrativa - Mente, evolução, cognição e linguagem". O evento dava sequência a duas publicações conjuntas que haviam sido realizadas por vários dos convidados presentes na revista Eutomia (UFPE), em 2014 e no próprio ano de 2015. O objetivo deste trabalho cooperativo era até então inédito na universidade brasileira: inaugurar um campo interdisciplinar de discussão sobre propostas recentes de naturalização do estudo da linguagem e da literatura que têm ganhado espaço em universidades estrangeiras, particularmente nos EUA. Em linhas gerais, o grupo propõe debater as contribuições incipientes, os limites e os potenciais desdobramentos de certas proposições advindas do estabelecimento de um diálogo ativo, pelos estudos linguísticos e, mais polemicamente, pelos estudos literários, com disciplinas que têm nas ciências biológicas os seus paradigmas epistemológicos de referência, em especial na teoria da evolução (em suas várias versões). Falamos da neurociência, da filosofia da mente, da ciência cognitiva, da evolução humana, da psicologia cognitiva, da sociobiologia, da memética, da teoria da relevância, da evolução da linguagem, da evolução cultural, campos de pesquisa que cada vez mais interessam a filósofos, linguistas e, de maneira incipiente, especialistas em literatura. Caminhando nesta direção, os artigos incluídos neste dossiê, de autoria de Adelaide Pescatori Silva, Caetano Galindo, Diogo Gurgel, Eduardo Vicentini, Gabriel Mograbi, Nazareno Almeida, Pedro Dolabela Chagas, Rodrigo Bueno, Elena Godoi e Maurício Benfatti, são a terceira publicação coletiva de um possível grupo de pesquisa em vias de constituição, que teve na UFPR o seu primeiro encontro presencial. Ao contrário das coletâneas anteriores, esta

* Universidade Federal do Paraná. 
comporta uma diferença importante: o foco estrito num tema principal, a narrativa (ficcional ou não). Ao redor desse tema gravitam as contribuições, que no mais preservam a heterogeneidade de sempre: num campo ainda em constituição, não há como eliminar a ausência de consensos claros quanto a paradigmas epistemológicos a serem compartilhados, ou sequer quanto à direção a ser conferida à pesquisa. Tampouco se pode deixar de notar a preferência dos autores pelo lançamento das suas proposições a partir da erudição, dos métodos e de resultados de pesquisa construídos em práticas disciplinares já consolidadas, a partir das quais as novas ideias são (seletivamente) apreciadas. Tudo isso aumenta a heterogeneidade dos textos - e com isso (ou ao menos assim o esperamos) a riqueza da sua disposição conjunta. Por fim, vale alertar para a ausência de "conclusões" que deles se possa coletivamente depreender: se o tema é assim tão novo mesmo para os próprios autores, bem mais importante da perspectiva do trabalho coletivo é, por ora, iniciar um mapeamento do campo, alinhavando os progressos realizados até aqui e avaliando possibilidades em curso - tal é a contribuição almejada pelo dossiê. 